\title{
PENGARUH PREDISPOSISI, ENABLING DAN REINFORCING TERHADAP UTILITAS POS PEMBINAAN TERPADU PENYAKIT TIDAK MENULAR
}

\author{
Evi Fitriani, ${ }^{1}$ Kiki Putri Anriani Harahap ${ }^{2}$ \\ Fakultas Kesehatan Masyarakat \\ Institut Kesehatan Deli Husada Delitua \\ Jalan Besar No 77 Delitua Deli Serdang \\ Email : evi.nasution89@gmail.com
}

\begin{abstract}
Non-Communicable Disease Integrated Development Post is manifestation of community participation in the activities of early detection, monitoring and action continued early PTM risk factors independently and continuously. This activity developed as a form of early awareness of PTM, remembering almost most PTM in the early stages are asymptomatic that are significant This study aims to analyze the influence of predisposing, enabling and reinforcing factors on Utilities for Integrated Coaching of NonCommunicable Diseases at the Danau Marsabut Health Center, Sipirok District, South Tapanuli Regency. This type of research is analytic with cross sectional research design. The population in this study were all PTM targets in PTM Posbindu totaling 3670 people from January to May 2018. The sample was 95 people with purposive sampling method. Data were analyzed by univariate, bivariate and logistic regression. The results showed that those who used Non-Communicable Disease Integrated Development Post were 64 people (67.4\%) and 31 people (32.6\%) who did not use it. There is the influence of knowledge ( $p$ value 0.001), attitude ( $p$ value 0.001 ), distance ( $p$ value 0.041 ), transportation ( $p$ value 0.001 ), family support ( $p$ value 0.004$)$, and officer attitudes ( $p$ value 0.014 ) to the utility of Non-Communicable Disease Integrated Development Post. The most influential variable on the utility is knowledge. It is recommended to the South Tapanuli District Health Office to monitor, controlling and evaluating the implementation of Non-Communicable Disease Integrated Development Post services in each Technical Implementation Unit (TIU) and hospitals in South Tapanuli Regency.
\end{abstract}

Keywords : Utilization, integrated post development of non-communicable diseases

\section{PENDAhUluan}

Pos Pembinaan Terpadu Penyakit Tidak Menular (Posbindu PTM) merupakan peran serta masyarakat dalam melakukan kegiatan deteksi dini dan pemantauan faktor risiko PTM Utama yang dilaksanakan secara terpadu, rutin, dan periodik. Faktor risiko penyakit tidak menular (PTM) meliputi merokok, konsumsi minuman beralkohol, pola makan tidak sehat, kurang aktifitas fisik, obesitas, stres, hipertensi, hiperglikemi, hiperkolesterol serta menindak lanjuti secara dini faktor risiko yang ditemukan melalui konseling kesehatan dan segera merujuk ke fasilitas pelayanan kesehatan dasar.

Kelompok PTM Utama adalah diabetes melitus (DM), kanker, penyakit jantung dan pembuluh darah (PJPD), penyakit paru obstruktif kronis (PPOK), dan gangguan akibat kecelakaan dan tindak kekerasan (Kemenkes, 2012).

Masalah kesehatan masyarakat yang dihadapi saat ini adalah makin meningkatnya kasus Penyakit Tidak Menular (PTM). PTM adalah penyakit yang bukan disebabkan oleh infeksi kuman 
termasuk penyakit kronis degeneratif, antara lain penyakit jantung, diabetes melitus (DM), kanker, penyakit paru obstruktif kronis (PPOK), dan gangguan akibat kecelakaan dan tindak kekerasan. Angka kematian PTM meningkat dari 41,7 \% pada tahun 1995 menjadi 59,5 \% pada tahun 2007 (Riskesdas, 2013).

Penyakit tidak menular (PTM) merupakan penyakit kronis yang tidak ditularkan dari orang ke orang. Data PTM meliputi : (1) asma; (2) penyakit paru obstruksi kronis (PPOK); (3) kanker; (4) DM; (5) hipertiroid; (6) hipertensi; (7) jantung koroner; (8) gagal jantung; (9) stroke; (10) gagal ginjal kronis; (11) batu ginjal; (12) penyakit sendi/rematik. Data penyakit asma/ mengi/ bengek dan kanker diambil dari responden semua umur, PPOK dari umur $\geq 30$ tahun, DM, hipertiroid, hipertensi /tekanan darah tinggi, penyakit jantung koroner, penyakit gagal jantung, penyakit ginjal, penyakit sendi/ rematik/ encok dan stroke ditanyakan pada responden umur $\geq 15$ tahun (Riskesdas, 2013).

Saat ini, penyakit tidak menular (PTM) menjadi penyebab kematian utama sebesar 36 juta (63\%) dari seluruh kasus kematian yang terjadi di seluruh dunia, di mana sekitar 29 juta (80\%) justru terjadi di negara yang sedang berkembang. Peningkatan kematian akibat PTM di masa mendatang diproyeksikan akan terus terjadi sebesar $15 \%$ (44 juta kematian) dengan rentang waktu antara tahun 2010 dan 2020 (WHO, 2010).

Dalam kurun waktu tahun 19952007, kematian akibat PTM mengalami peningkatan dari $41,7 \%$ menjadi $59,5 \%$. Berdasarkan Riset Kesehatan Dasar 2013 menunjukkan prevalensi penyakit stroke 12,1 per 1000 , penyakit jantung koroner $1,5 \%$, gagal jantung $0,3 \%$, diabetes melitus $6,9 \%$, gagal ginjal $0,2 \%$, kanker 1,4 per 1000 , penyakit paru obstruksi kronik 3,7\% dan cidera 8,2\% (Riskesdas, 2013).
Pada awalnya perjalanan PTM seringkali tidak bergejala dan tidak menunjukkan tanda klinis secara khusus sehingga datang sudah terlambat atau pada stadium lanjut akibat tidak mengetahui dan menyadari kondisi kelainan yang terjadi pada dirinya. Riset Kesehatan Dasar pada tahun 2013 menunjukkan bahwa 69,6\% dari kasus diabetes melitus dan $63,2 \%$ dari kasus hipertensi masih belum terdiagnosa. Keadaan ini mengakibatkan penanganan menjadi sulit, terjadi komplikasi bahkan berakibat kematian lebih dini.

Upaya pengendalian PTM dibangun berdasarkan komitmen bersama dari seluruh elemen masyarakat yang peduli terhadap ancaman PTM melalui Posbindu PTM. Pengembangan Posbindu PTM merupakan bagian integral dari sistem pelayanan kesehatan, diselenggarakan berdasarkan permasalahan PTM yang ada di masyarakat dan mencakup berbagai upaya promotif dan preventif serta pola rujukannya.

Bertitik tolak dari hal-hal di atas maka peneliti tertarik untuk melakukan penelitian dengan judul penelitian "Faktorfaktor yang mempengaruhi utilisasi Posbindu PTM Puskesmas Danau Marsabut Kecamatan Sipirok Kabupaten Tapanuli Selatan Tahun 2018."

\section{METODE PENELITIAN}

Jenis penelitian ini adalah analitik dengan rancangan penelitian cross sectional yang bertujuan untuk mengetahui Faktorfaktor Yang Mempengaruhi terhadap Utilitas Pos Pembinaan Terpadu Penyakit Tidak Menular (POSBINDU PTM) di Puskesmas Danau Marsabut Kecamatan Sipirok, Kabupaten Tapanuli Selatan tahun 2018.

Sampel adalah sebagian dari wilayah generalisasi objek/subjek yang memiliki karakteristik/sifat tertentu yang akan dikaji oleh peneliti untuk ditarik sebuah kesimpulan (Sugiono, 2013). Sampel dalam penelitian ini adalah sebagian populasi sasaran PTM di Pos Pembinaan Terpadu Penyakit Tidak Menular di Puskesmas Danau Marsabut Kecamatan Sipirok Kabupaten Tapanuli Selatan tahun 
2018. Besar sampel dihitung dengan memanfaatkan rumus sampel minimum dari Lemeshow, yaitu sebesar 95 orang.

Analisis data meliputi univariat, bivariat dengan uji chi square dan multivariat dengan uji regresi logistik.

\section{HASIL PENELITIAN}

Karakteristik responden pada penelitian ini meliputi umur, jenis kelamin, pendidikan, pekerjaan, dan waktu tempuh ke puskesmas. Untuk lebih rinci dapat dilihat sebagai berikut :

Tabel 3.1. Distribusi Karakteristik Responden di Wilayah Kerja Puskesmas Danau Marsabut Tahun 2018

\begin{tabular}{ccc}
\hline Karakteristik & Jumlah (n) & \% \\
\hline 1. Umur & & \\
$>40$ Tahun & 33 & 34,7 \\
$\leq 40$ Tahun & 62 & 65,3 \\
$\quad$ Jumlah & $\mathbf{9 5}$ & $\mathbf{1 0 0 , 0}$ \\
2. Jenis Kelamin & & \\
$\quad$ Laki laki & 37 & 38,9 \\
$\quad$ Perempuan & 58 & 61,1 \\
$\quad$ Jumlah & $\mathbf{9 5}$ & $\mathbf{1 0 0 , 0}$ \\
3. Pekerjaan & & \\
$\quad$ Tetap & 36 & 37,9 \\
$\quad$ Tidak Tetap & 59 & 62,1 \\
$\quad$ Jumlah & $\mathbf{9 5}$ & $\mathbf{1 0 0 , 0}$ \\
4. Pendidikan & & \\
$\quad$ Tinggi & 32 & 33,7 \\
Rendah & 63 & 66,3 \\
Jumlah & $\mathbf{9 5}$ & $\mathbf{1 0 0 , 0}$ \\
5. Waktu Tempuh & & \\
Singkat & 60 & 63,2 \\
Lama & 35 & 36,8 \\
Jumlah & $\mathbf{9 5}$ & $\mathbf{1 0 0 , 0}$ \\
\hline
\end{tabular}

Penelitian ini sebahagian besar berusia $\leq 40$ tahun $(65,3 \%)$ dan $>40$ Tahun sebesar (34,7\%). Perempuan sebesar $(61,1 \%)$ dan laki-laki sebesar $(38,9 \%)$. sebagian besar pendidikan rendah $(66,3 \%)$ dan tinggi $(33,7 \%)$. pekerjaan tidak tetap sebesar $(62,1 \%)$ dan pekerjaan tetap sebesar (37,9\%). Sebagian besar waktu tempuh singkat sebesar $(63,2 \%)$ dan waktu tempuh lama $(36,8 \%)$.

Tabel 3.2. Analisis Univariat

\begin{tabular}{ccc}
\hline Variabel & $\begin{array}{c}\text { Jumlah } \\
(\mathbf{n})\end{array}$ & $\begin{array}{c}\text { Persentase } \\
(\mathbf{\%})\end{array}$ \\
\hline Pengetahuan & & \\
Baik & 71 & 74,7 \\
Tidak Baik & 24 & 25,3 \\
Jumlah & $\mathbf{9 5}$ & $\mathbf{1 0 0 , 0}$ \\
Sikap & & \\
Baik & 66 & 69,5 \\
Tidak Baik & 29 & 30,5 \\
Jumlah & $\mathbf{9 5}$ & $\mathbf{1 0 0 , 0}$ \\
Jarak & & \\
Dekat & 64 & 67,4 \\
Jauh & 31 & 32,6 \\
Jumlah & $\mathbf{9 5}$ & $\mathbf{1 0 0 , 0}$ \\
Transportasi & & \\
Lancar & 71 & 74,7 \\
Tidak Lancar & 24 & 25,3 \\
Jumlah & $\mathbf{9 5}$ & $\mathbf{1 0 0 , 0}$ \\
Dukungan & & \\
Keluarga & & \\
Baik & 71 & 74,7 \\
Tidak Baik & 24 & 25,3 \\
Jumlah & $\mathbf{9 5}$ & $\mathbf{1 0 0 , 0}$ \\
Sikap & & \\
Petugas & & $\mathbf{2 7 , 9}$ \\
Baik & 74 & $\mathbf{1 0 0 . 0}$ \\
Tidak Baik & 21 & \\
Total & $\mathbf{9 5}$ & \\
\hline
\end{tabular}

Distribusi responden berdasarkan faktor pengetahuan dalam penelitian ini sebagian besar mengatakan baik sebesar $(74,7 \%)$ dan tidak baik sebesar (25,3\%). Distribusi responden berdasarkan faktor sikap dalam penelitian ini sebagian besar mengatakan sikap baik $(69,5 \%)$ dan tidak baik sebesar $(30,5 \%)$. Distribusi responden berdasarkan faktor jarak dalam penelitian ini sebagian besar mengatakan jarak dekat sebesar $(67,4 \%)$ dan jarak jauh sebesar (32,6\%).

Distribusi responden berdasarkan faktor transportasi dalam penelitian ini 
sebagian besar mengatakan transportasi lancar sebesar $(74,7 \%)$ dan tidak lancar sebesar (25,3\%). Distribusi responden berdasarkan faktor dukungan keluarga dalam penelitian ini sebagian besar menunjukan dukungan keluarga baik sebesar $(74,7 \%)$ dan tidak baik sebesar (25,3\%). Distribusi responden berdasarkan faktor sikap petugas dalam penelitian ini sebagian besar menunjukan baik sebesar $(77,9 \%)$ dan tidak baik sebesar $(22,1 \%)$. Distribusi responden berdasarkan utilitas PTM responden dalam penelitian ini sebagian besar memanfaatkan sebesar $(67,4 \%)$ dan tidak memanfaatkan sebesar $(32,6 \%)$.

Tabel. 3. 3. Hasil Analisis Bivariat

\begin{tabular}{lcc}
\hline Variabel & $\begin{array}{c}\boldsymbol{P} \\
\text { Value }\end{array}$ & PR \\
\hline Pengetahuan & 0,001 & 5,729 \\
Sikap & 0,001 & 5,262 \\
Jarak & 0,041 & 2,813 \\
Transportasi & 0,001 & 5,729 \\
Dukungan & 0,004 & 4,447 \\
keluarga & & \\
Sikap & 0,014 & 3,860 \\
petugas & \\
\hline
\end{tabular}

Berdasarkan hasil uji bivariat semua variable berpengaruh terhadap pemanfaatan pelayanan Posbindu PTM di puskesmas Danau Marsabut Tahun 2018.

Tabel 3.4. Hasil Analisis Multivariat Regresi Logistik

\begin{tabular}{lccc}
\hline Variabel & B & P value & RP \\
\hline Pengetahuan & 1.253 & 0.025 & 3.502 \\
Sikap & 1.196 & 0.024 & 3.306
\end{tabular}

Berdasarkan hasil analisis multivariate dengan regresi logistik nilai prevalence ratio untuk variable sikap sebesar 3,306 artinya sikap responden yang tidak baik 3,306 kali lebih besar memungkinkan responden untuk tidak memanfaatkan posbindu PTM dibandingkan responden yang bersikap baik.. Regresi logistik nilai prevalence ratio untuk variable pengetahuan sebesar 3,502 artinya pengetahuan yang tidak baik dari responden 3,502 kali lebih besar memungkinkan responden untuk tidak memanfaatkan posbindu PTM dibandingkan responden yang berpengetahuan baik.

\section{PEMBAHASAN}

Berdasarkan analisis bivariat menunjukkan hasil bahwa $77,5 \%$ responden berpengetahuan baik memanfaatkan pelayanan Posbindu PTM. Berdasarkan hasil uji chi-square antara variabel pengetahuan dengan utilisasi Posbindu PTM diperoleh nilai $p$ sebesar 0,001 , artinya ada pengaruh yang bermakna antara variabel pengetahuan dengan utilisasi Posbindu PTM.

Menurut Notoatmodjo (2005), pengetahuan merupakan indikator dari orang melakukan tindakan dengan sesuatu. Jika seseorang didasari oleh pengetahuan yang baik dengan kesehatan maka orang tersebut akan memahami bagaimana kesehatan itu dan mendorong untuk mengaplikasikan apa yang diketahuinya. Pengetahuan memegang peranan penting dalam membawa seseorang berpikir dan berusaha untuk melakukan tindakan yang benar. Pengetahuan merupakan suatu hal yang sangat dibutuhkan dalam rangka perubahan pola pikir dan perilaku dalam masyarakat. Pengetahuan ini terkait dengan lingkungan dimana responden menetap. Selain itu, keterpaparan dengan media komunikasi akan memengaruhi kadar pengetahuannya. Tidak mungkin mereka dapat terpapar dengan kondisi yang sesuai dengan kondisi saat ini sementara daerah tempat tinggalnya jauh dari keramaian dan keterjangkauan sarana pelayanan publik.

Hasil penelitian tentang variabel pengetahuan ditemukan bahwa pengetahuan yang baik memanfaatkan ANC sebanyak $77,8 \%$. Uji statistic menunjukkan variabel pengetahuan berpengaruh dengan pemanfaatan ANC. Mengacu pada hasil uji tersebut dapat dijelaskan semakin baik pengetahuan ibu hamil maka akan meningkat pemanfaatan ANC, Sihombing (2012). 
Berdasarkan hasil analisis bivariat menunjukkan responden yang bersikap baik $78,8 \%$ memanfaatkan pelayanan posbindu PTM. Hasil uji chi-square antara variabel sikap dengan utilisasi posbindu PTM diperoleh nilai psebesar 0,001, artinya ada pengaruh yang bermakna antara variabel sikap dengan utilisasi Posbindu PTM. Hasil analisis diketahui bahwa responden dengan sikap yang baik dapat diartikan sikap yang positif dengan utilisasi Posbindu PTM.

Dari hasil wawancara dengan responden diketahui bahwa responden setuju dengan semua pelayanan yang diberikan dalam Posbindu PTM, karena menyediakan pelayanan kesehatan yang bermanfaat serta melaksanakan program sesuai dengan kebutuhan masyarakat. Selain itu, petugas yang memberikan pelayanan Posbindu PTM tersebut melakukan pelayanan dengan ramah dan baik. Sehingga hasil penelitian menunjukkan sikap responden dalam kategori baik sudah banyak yang memanfaatkan pelayanan Posbindu PTM.

Sikap merupakan reaksi atau respon yang masih tertutup dari seseorang dengan stimulus atau objek sikap mempunyai tiga komponen pokok yaitu kepercayaan (ide) dengan suatu objek, kehidupan emosional atau evaluasi dengan suatu objek, dan kecenderungan untuk bertindak (Notoatmodjo, 2005).

Hasil penelitian Effendi (2012) diperoleh bahwa ada pengaruh sikap dukun bayi dengan tindakan pertolongan persalinan oleh dukun bayi di Kecamatan Baktiya Kabupaten Aceh Utara.

Berdasarkan hasil analisis bivariat menunjukkan variabel jarak dengan kategori dekat $75,0 \%$ memanfaatkan pelayanan posbindu PTM. Hasil uji chi-square antara variabel jarak dengan utilisasi posbindu PTM diperoleh nilai $p$ sebesar 0,041 , artinya ada pengaruh yang bermakna antara variabel jarak dengan utilisasi Posbindu PTM. Hasil analisis diketahui bahwa responden yang memiliki jarak rumah yang dekat $(\leq 5 \mathrm{~km})$ dengan posbindu PTM dapat diartikan sebagai faktor pendukung responden dalam memanfaatkan pelayanan Posbindu PTM.

Menurut Dever (1984) dalam Suriati (2009), akses geografi adalah faktor-faktor geografi yang memudahkan atau menghambat pemanfaatan pelayanan kesehatan, berkaitan dengan jarak tempuh, waktu tempuh dan biaya tempuh. Pengaruh antara akses geografi dengan volume penggunaan pelayanan tergantung dari jenis pelayanan dan jenis sumber daya yang ada. Peningkatan akses yang disebabkan oleh berkurangnya jarak, waktu tempuh ataupun biaya tempuh mengakibatkan peningkatan pelayanan yang berpengaruh dengan keluhan-keluhan ringan, atau pemakaian pelayanan preventif akan lebih tinggi daripada pelayanan kuratif, sebagaimana halnya dengan pemanfaatan pelayanan umum bila dibandingkan dengan pelayanan spesialis. Semakin berat suatu penyakit atau keluhan dan semakin canggih atau semakin khusus sumber daya pelayanan, semakin kuat pengaruh antara akses geografis dan volume pemanfaatan pelayanan.

Jarak menciptakan gangguan karena dibutuhkan waktu dan tenaga (biaya) untuk mencapai lokasi yang satu dari lokasi lainnya. Selain itu, jarak juga menciptakan gangguan informasi sehingga semakin jauh dari suatu lokasi makin kurang diketahui potensi/karakter yang terdapat pada lokasi tersebut. Makin jauh jarak yang ditempuh, makin menurun minat seseorang untuk bepergian dengan asumsi faktor lain semuanya sama (Tarigan, 2009).

Penelitian Harahap (2012),

berdasarkan hasil uji regresi logistik ganda menunjukkan ada pengaruh signifikan jarak tempuh dengan pemanfaatan pelayanan kesehatan dengan koefisien regresi $(\beta)=$ 2,113 , probabilitas $(p)=0,005$, dan $\operatorname{Exp}(\beta)=8,270$. Dari 55 responden dengan jarak tempuh dekat sebagian besar memanfaatkan rumah sakit dalam kategori tinggi yaitu 43 orang (40,6\%).

Hasil penelitian Siregar (2012) menunjukkan bahwa dari 59 orang ibu yang menyatakan lokasi sarana pertolongan 
persalinan dekat, sebanyak 38 orang $(64,4 \%)$ memilih tenaga kesehatan sebagai penolong persalinan. Demikian juga dari 37 orang ibu yang menyatakan lokasi sarana pertolongan persalinan jauh, sebanyak 34 orang $(91,9 \%)$ memilih tenaga kesehatan sebagai penolong persalinan. Hasil uji chi square diperoleh nilai $p=0,002<0,05$, dengan demikian terdapat pengaruh antara lokasi sarana pertolongan persalinan dengan pemilihan penolong persalinan.

Hasil analisis diketahui bahwa transportasi yang lancar merupakan peluang yang besar bagi responden dalam memanfaatkan pelayanan posbindu PTM, dengan kata lain responden tidak mengalami kesulitan dalam mengakses sarana transportasi dalam menempuh Posbindu PTM.

Menurut Sukarto (2006) dalam Purnomo (2012), transportasi mendukung perkembangan kota dan wilayah sebagai sarana penghubung. Rencana tata guna lahan kota harus didukung secara langsung oleh rencana pola jaringan jalan yang merupakan rincian tata guna lahan yang direncanakan. Pola jaringan jalan yang baik akan mempengaruhi perkembangan kota sesuai dengan rencana tata guna lahan. Ini berarti transportasi mendukung penuh dengan perkembangan fisik suatu kota atau wilayah sehingga kota dapat teratur terutama jika dilakukan dari sistem berlalu lintas.

Kemudahan transportasi membuat seseorang menjadi mudah untuk dapat mengunjungi sekian banyak pertemuan dari sekian banyak kegiatan ataumemudahkan seseorang untuk mencapai tempat yang dituju. Dengan kata lain, kemudahan transportasi membuat kemudahan pada mobilitas sosial bagi pelaku sosial (Sudjarwo, 2011).

Dalam penelitian ini sebagian besar responden mengatakan transportasi untuk mencapai Posbindu PTM Kabupaten Tapanuli Selatan dalam kategori lancar (74,7\%). Untuk beberapa responden yang tinggal di pelosok desa tidak akan mengalami kesulitan untuk mendapatkan angkutan ke posbindu PTM, karena angkutan selalu ada dan tidak menggunakan waktu-waktu tertentu (misalnya hanya pagi dan sore hari baru ada trayeknya). Selain itu beberapa responden mempunyai mobil pribadi yang dapat digunakan setiap waktu. Transportasi pada masa kini merupakan moda angkutan yang paling penting sebagai alat mobilisasi seseorang dari satu tempat ke tempat lainnya.

Menurut Sarwono (2003), dukungan adalah suatu upaya yang diberikan kepada orang lain, baik moril maupun materil untuk memotivasi orang tersebut dalam melaksanakan kegiatan. Banyak faktor yang dapat menyebabkan responden memanfaatkan pelayanan posbindu PTM, salah satunya karena faktor psikologis, di mana dukungan moral dari keluarga memiliki andil yang besar. Keluarga sebagai orang yang paling dekat dengan responden memiliki peran serta dalam memberikan dukungan dengan responden dalam memanfaatkan dalam pelayanan posbindu PTM. Hasil penelitian menunjukkan dari 95 responden, 71 orang memiliki dukungan keluarga yang baik, sehingga masyarakat sudah banyak yang memanfaatkan pelayanan Posbindu PTM.

Penelitian Sirait menunjukkan hasil tabulasi silang antara pelayanan bidan dengan pemanfaatan pelayanan jampersal diperoleh data bahwa jumlah responden yang menyatakan pelayanan bidan baik yang memanfaatkan pelayanan Jampersal yaitu sebanyak $47,47 \%$ .Hasil uji statistik fisher diperoleh nilai $p=$ 0,001 artinya ada pengaruh yang bermakna antara pelayanan bidan dengan pemanfaatan pelayanan Jampersal di wilayah kerja Puskesmas Parongil Kabupaten Dairi.

Dari hasil wawancara dengan 95 responden, sebanyak 74 orang mengatakan sikap petugas sudak baik. Hal ini disebabkan masyarakat puas dengan pelayanan dan sikap petugas yang baik dan ramah. Petugas juga memberikan informasi yang bermanfaat 
dan sesuai dengan yang dibutuhkan oleh masyarakat. Selain itu, petugas bekerja secara professional dan disiplin melakukan kegiatan posbindu PTM serta memberi motivasi kepada sasaran PTM untuk melakukan pola hidup sehat, sehingga dapat mencegah kejadian penyakit tidak menular pada diri mereka sendiri.

Hasil penelitian Dahlan (2005) yang menyatakan bahwa pelayanan personil (dokter dan bidan) yang ramah, sabar mendengarkan keluhan pasien dan memberikan informasi yang dibutuhkan pasien tentang penyakit dan pengobatan yang sedang dijalani dan keputusan untuk memanfaatkan pelayanan rujukan ibu hamil beresiko di rumah sakit umum di Kabupaten Deli Serdang. Demikian pula penelitian yang dilakukan oleh Harahap (2006) bahwa pelayanan dokter yang lebih cenderung mengarah ke kuratif tanpa diimbangi upaya preventif berupa saran sangat memengaruhi kepuasan pasien dalam pelayanan kesehatan.

\section{KESIMPULAN}

Berdasarkan hasil penelitian faktor pengetahuan, sikap, jarak, transportasi, dukungan keluarga dan sikap petugas, keenam variable berpengaruh signifikan terhadap utilitas posbindu PTM dan pengetahuan adalah variabel yang paling berpengaruh terhadap pemanfaatan posbindu PTM di Puskesmas Danau Marsabut Kecamatan Sipirok Kabupaten Tapanuli Tengah Tahun 2018.

\section{DAFTAR PUSTAKA}

Bangsu, Tamrin. Dukun Bayi Sebagai Pilihan Utama Tenaga Penolong Persalinan. Jurnal Penelitian UNIB, Vol. VII, No. 2, Juli 2001, Hal. 104-109. diakses April 2012.

Dahlan, S., 2010. Statistik untuk Kedokteran dan Kesehatan, Edisi ketiga, Jakarta : Salemba Medika.

Dencker A. att all 2010. Childbirth experience questionnaire (CEQ): Development and Evaluation of a multidimensional instrument. Reseach Article.

Harahap,N, 2012. Pengaruh letak geografis dan kualitas pelayanan kesehatan terhadap pemanfaatan pelayanan kesehatan oleh pasien di Rumah Sakit Umum Daerah Kabupaten Tapanuli Selatan. (Tesis), Medan : Program Studi Ilmu Kesehatan Masyarakat Program Pasca Sarjana Universitas Sumatera Utara.

Ilyas,2003. Pemanfaatan Pelayanan Kesehatan.

http://www.psychologymania.co m/2012/06/pemanfaatanpelayanan kesehatan.html. diakses tanggal 1 Maret 2013.

Imron, M.dan Munif, A., 2010. Metodologi Penelitian Bidang Kesehatan. Sagung Seto, Jakarta.

Megawati, 2005. Analisis Pengaruh Karakteristik Individu Terhadap Kinerja Perawat di RSU Pirngadi Medan Tahun 2004. (Tesis), Medan : Program Studi Ilmu Kesehatan Masyarakat Program Pasca Sarjana Universitas Sumatera Utara.

Mikrajab, M. A. 2011. Determinan Kinerja Bidan di Puskesmas Tahun 2006. Jurnal Manajemen Pelayanan Kesehatan.

Nogi, H., 2003. Kebijakan Publik yang Membumi, Lukman Offset, Yogyakarta.

Notoatmodjo, S., 2003. Pengantar Pendidikan Kesehatan dan Ilmu Perilaku. Rineka Cipta. Jakarta.

Nurianti, I., 2012. Pengaruh Faktor Predisposisi, Pendukung dan Kebutuhan terhadap Pemanfaatan Penolong Persalinan pada Ibu Bersalin di Wilayah Kerja Puskesmas Binjai Serbangan Kabupaten Asahan (Tesis) Pasca Sarjana FKM Universitas Sumatera Utara.

Rifai, 2005. Pengaruh Persepsi Masyarakat Terhadap Pemanfaatan 


\begin{abstract}
Pelayanan Pengobatan di
Puskesmas Binjai Kota Tahun

2004 (Tesis), Medan : Program

Magister Administrasi Kebijakan

Kesehatan Program Studi IImu

Kesehatan Masyarakat Program

Pasca Sarjana Universitas

Sumatera Utara.
\end{abstract}

Sihombing, F, 2012. pengaruh faktor predisposisi, kebutuhan dan pemungkin terhadap pemanfaatan Antenatal Care (ANC) di wilayah kerja Puskesmas Simpang Limun Kota Medan.(Tesis), Medan : Program Studi Ilmu Kesehatan Masyarakat Program Pasca Sarjana Universitas Sumatera Utara.

Simanjuntak, L., 2012. Pengaruh Pengetahuan dan Kepercayaan Pasien terhadap Pengambilan Keputusan Persalinan Sectio Caesaria di RSU HKBP Balige Tahun 2012 (Tesis), Medan : Program Magister Administrasi Kebijakan Kesehatan Program Studi IImu Kesehatan Masyarakat Program Pasca Sarjana Universitas Sumatera Utara. 